\title{
Leaf damage has weak effects on growth and fecundity of common ragweed (Ambrosia artemisiifolia)
}

Post-print/Accepted manuscript

A. Andrew M. MacDonald

Peter M. Kotanen

MacDonald AAM, Kotanen PM. 2010. Leaf damage has weak effects on growth and fecundity of common ragweed (Ambrosia artemisiifolia). Botany 88(2): 158-164 doi:10.1139/B09-110

\section{HOW TO CITE TSPACE ITEMS}

Always cite the published version, so the author(s) will receive recognition through services that track citation counts, e.g. Scopus. If you need to cite the page number of the TSpace version (original manuscript or accepted manuscript) because you cannot access the published version, then cite the TSpace version in addition to the published version using the permanent URI (handle) found on the record page. 


\title{
Leaf damage has weak effects on growth and fecundity of common
}

\section{ragweed (Ambrosia artemisiifolia)}

\author{
A. Andrew M. MacDonald ${ }^{1}$ and Peter M. Kotanen ${ }^{2 *}$ \\ Department of Ecology and Evolutionary Biology \\ University of Toronto Mississauga \\ 3359 Mississauga Road N \\ Mississauga ON L5L 1C6, Canada \\ tel: 905-828-5365; fax: 905-828-3792 \\ 1e-mail: andrewm.macdonald@utoronto.ca \\ 2e-mail: peter.kotanen@utoronto.ca \\ * Author for correspondence
}

Length: 3721 words excluding references and figure captions; 5140 words overall; 22 pages 


\begin{abstract}
:
The Enemy Release Hypothesis predicts that exotic plants gain an advantage over native competitors by losing their natural enemies while invading new regions. However, this assumes that these enemies previously must have reduced the performance of these invaders in their native ranges; this may not be true if an invader is highly herbivore-tolerant. We used a field experiment to test the herbivore tolerance of a North American annual, common ragweed (Ambrosia artemisiifolia L.), which is known to have lost insect herbivores while invading Europe. We clipped leaves to simulate damage by folivores and removed meristems to simulate apical mortality caused by stem borers, and measured the consequences for growth and reproduction. Stem biomass was reduced only by defoliation far in excess of native-range natural damage, while seed production was unaffected by our treatments. Severely damaged plants maintained seed production by allocating relatively more above-ground biomass to reproduction. These results suggest damage by natural enemies often may have few consequences for this highly tolerant plant; consequently, enemy release may not have provided a significant advantage to this species in Europe. As well, biological control by insect folivores is unlikely to succeed unless it results in very high levels of damage.
\end{abstract}

Key words: Biological invasions, enemy release, herbivore tolerance, insect herbivores, natural enemies, simulated damage 


\section{Introduction}

The Enemy Release Hypothesis proposes that invading plants often lose their natural enemies (herbivores and pathogens) during their colonization of new areas, providing them with an advantage over native competitors (Elton 1958; Keane and Crawley 2002; Torchin and Mitchell 2004; Mitchell et al. 2006). Recent reviews have indicated that invaders often do escape enemies in new areas (Mitchell and Power 2003; Liu and Stiling 2006); nonetheless, this hypothesis remains controversial (Colautti et al. 2004). One reason for this uncertainty is that it is often unclear whether invaders are limited by enemies within their native range, and therefore whether escaping enemies during invasion provides a significant demographic benefit (Maron and Vilà 2001; Hierro et al. 2005). Even in native regions, natural enemies may not be sufficiently abundant to seriously damage their host plants. As well, even when enemies are abundant, many plants possess tolerance traits that help to maintain fitness after damage (Rosenthal and Kotanen 1994; Strauss and Agrawal 1999; Stowe et al. 2000), buffering them against top-down control (Tiffin 2000). For instance, Bossdorf et al. (2004) found that removing 75\% of the leaf area of the invasive Alliaria petiolata (M. Bieb.) Cavara \& Grande (garlic mustard) reduced fitness by only $19 \%$. Such highly tolerant invaders should be less likely to benefit from enemy release.

Common ragweed (Ambrosia artemisiifolia L.) is a good model for investigating these issues.

This North American annual is both an agricultural and human health pest throughout much of Europe, where it spread during the last two centuries (Allard 1943; Chauvel et al. 2006). Previous studies have confirmed that ragweed has indeed experienced escape from enemies during this invasion: at least in France, individuals are much less attacked by insects than Canadian populations (Genton et al. 2005). Despite this, there is good reason to question whether this escape has increased the invasiveness of this species. In its native region, MacKay and Kotanen (2008) observed that plants more heavily damaged by herbivores were not smaller or less fecund. Likewise, in a manipulative study at the same location, Macdonald and Kotanen (in revision) found that protection with insecticides did not increase growth or 
reproduction. Finally, Genton et al. (2005) found foliar damage in both native and invaded areas was negatively correlated with plant height, but this did not result in greater biomass in non-native areas despite greatly reduced herbivore pressure. These studies suggest that the performance of ragweed is not strongly reduced by natural enemies in its northern native range, and therefore that it cannot have benefitted significantly from enemy release while invading Europe.

One reason for the lack of native-range control likely is low average densities of natural enemies: natural damage rates tend to be moderate at best (MacKay and Kotanen 2008; MacDonald and Kotanen in revision). However, little is known about ragweed's herbivore tolerance. Circumstantial evidence suggests that ragweed is highly tolerant to defoliation; for instance, it often can survive (though in a stunted form) in infrequently mowed lawns and roadsides. A high degree of tolerance would further lessen the impacts of native-range insects, even if they can reach high densities in some situations.

In this paper, we ask the question: how tolerant is ragweed to defoliation? To answer this, we applied artificial damage treatments representing impacts of two different guilds of native-range herbivores: apical damage by stem borers, and tissue removal by leaf chewers. Using artificial damage rather than natural damage ensured that defoliation was independent of other factors affecting performance, a problem which can seriously bias estimates of tolerance based on natural patterns of herbivory (Tiffin and Inouye 2000). For example, MacKay and Kotanen (2008) provided evidence that herbivores prefer larger plants; estimating tolerance using natural levels of damage therefore could produce a misleading result. As well, use of artificial damage allowed us to simulate damage well in excess of natural levels, as might be expected in a highly successful biocontrol program or in an outbreak year for native herbivores; rates of herbivory on A. artemisiifolia can vary substantially between years (MacDonald and Kotanen in revision). For each damage type, we asked two questions: i) does damage decrease growth and fecundity, and ii) does damage alter the relationship between size and fecundity? Our results provide further evidence that the invasion of Europe by ragweed may not have been promoted by enemy release, even though herbivore damage is reduced in non-native 
populations.

\section{Materials and Methods}

Study site

This experiment was conducted at the Koffler Scientific Reserve at Jokers Hill (http://www.ksr.utoronto.ca), a 350 ha field station owned by the University of Toronto and situated near Newmarket, Ontario $\left(44^{\circ} 03^{\prime} \mathrm{N}, 79^{\circ} 29^{\prime} \mathrm{W}\right)$. The site used was an old field dominated by a mix of perennial grasses (Bromus inermis Leyss., Festuca arundinacea Schr.) and dicots (Cirsium spp., Asclepias syriaca L.). Ragweed is common at this location in general and the experimental site in particular.

Study species

Ragweed is a spring annual (Bazzaz 1974), germinating in May at our study site. It is highly disturbance-dependent and is excluded by dense vegetation (Bazzaz and Mezga 1973; Foster et al. 1980; Stevens and Carson 1999; Fumanal et al. 2008) but grows readily in weedy, open habitats such as cleared fields (Bazzaz 1968, 1974; Maryushkina 1991; Kosola and Gross 1999). It is difficult to eradicate from a site once established because of its very long-lived seed bank (Baskin and Baskin 1980). It is widespread throughout its native North America (Bassett and Terasmae 1962; Bassett and Crompton 1975; Teshler et al. 2002), where its abundant wind-dispersed pollen is used by palynologists as an indicator of past human disturbance (McAndrews 1988). This pollen is highly allergenic and a principal cause of hayfever (Bassett and Crompton 1975; Kiss 2007). Ragweed is a serious weed of crops and disturbed sites in North America (Bazzaz 1974; Bassett and Crompton 1975), and has been widely introduced throughout much of Europe, where it occupies similar sites (Kiss 2007).

In its native range, ragweed is attacked by a wide variety of invertebrate herbivores, including both generalists and specialists (Futuyma and McCafferty 1990; Funk et al. 1995; Teshler et al. 2002; MacKay and Kotanen 2008). During its invasion of Europe, it appears to have escaped from most of 
these natural enemies: damage is frequent in North America but uncommon in France (Genton et al. 2005). Both leaf chewing and stem boring herbivores are common at our site. The leaf chewers we most commonly observed during this experiment were Zygogramma suturalis F. (Coleoptera:

Chrysomelidae), Systena blanda Melshimer (Coleoptera: Chrysomelidae), and Tarachidia spp. (Lepidoptera: Noctuidae); the commonest stem borer was Epiblema strenuata Walker (Lepidoptera: Torticidae).

\section{Experimental design}

Ragweed is a very plastic species (e.g., Paquin and Aarssen 2004; Throop 2005); in response, we used a common garden approach to minimize uncontrolled environmental variation. In June of 2008, we plowed a $30 \mathrm{~m} \times 30 \mathrm{~m}$ experimental plot, clearing away the pre-existing old field vegetation. We then planted 150 ragweed seedlings collected from a nearby wild population, in ten rows of 15 plants each; rows were separated by $2 \mathrm{~m}$, and neighbouring plants by $1 \mathrm{~m}$. The seedlings used had 1-2 pairs of mature leaves and were less than $6 \mathrm{~cm}$ high at the time of transplanting. Plants were watered for two days following planting to protect against transplant shock; seedlings dying within this period were replaced (9 individuals).

Each row received one of five treatments; two non-adjacent rows were assigned to each treatment ( $n=30$ plants per treatment). Our five treatments were three levels of leaf removal (5\%, 25\% and 75\%), apical meristem removal, and an undamaged control. For the meristem removal treatment, the tip of the main shoot was clipped off with scissors; this simulates the mortality of apical meristems which commonly results from the presence of a boring insect in the main stem. Leaves were removed by clipping the petiole close to the stem; this generically simulates the removal of leaf area by folivores, though not necessarily any specific pattern of natural damage. For the $5 \%$ treatment, only fully expanded leaves near the top of plants were removed; for the more severe treatments, leaves were removed evenly throughout the entire plant. Because we removed whole leaves, we delayed application of the $5 \%$ treatment until most plants in this treatment had at least 20 leaves: treatments were applied to 
the $25 \%, 75 \%$, and meristem removal treatments on 16 July 2008 and to the $5 \%$ treatment on 28 July 2008. On 26 August 2008, all treatments were applied again. Although each row received only one treatment, we do not believe spatial confounding (pseudoreplication: Hurlbert 1984) to be a problem for several reasons: 1) all plants shared the same common environment provided by the common garden; 2) all treatments were spatially replicated in two of the 10 rows; 3) there is no reason to believe the plants in a row shared an environment distinct from that of other rows; and 4) since this experiment was a grid system, plants in a row were not isolated from other treatments, but instead were closer to plants in other rows than to most members of their own row.

In September we collected all surviving plants; at this time growth had ceased and seeds had matured. After collection, plants were allowed to dry at room temperature before weighing. For each plant we recorded stem weight and the total weight of seeds trapped by a $1.4 \mathrm{~mm}$ sieve. Stem weight is a better estimate of plant size (excluding roots) than total biomass since it was not directly reduced by our tissue removal treatments; thus, it represents an unbiased estimate of growth. Whole-plant seed weight is strongly related to seed number (both variables log-transformed, $\mathrm{F}_{1,36}=941.9, \mathrm{r}^{2}=0.96, \mathrm{p}<<$ 0.001), and therefore is a good proxy for fecundity.

\section{Analyses}

To test whether damage reduced growth or fecundity relative to controls, we used linear regression (for leaf removal) and t-tests (for meristem removal) for both stem biomass and seed biomass. Leaf damage was treated as a replicated but continuous independent variable (Sokal and Rohlf 1995). Meristem removal was analyzed separately from leaf damage since it represents a qualitatively different form of damage. Stem and seed biomass were $\log _{\mathrm{e}}$-transformed before analysis, both to normalize residual variance, and because the relationship between growth and fecundity often obeys a power law (e.g., Dodd and Silvertown 2000) which can be linearized by log-transformation.

To investigate how different damage treatments alter the relationship between above-ground plant size and fecundity, we performed analyses of covariance using the factorial model: 
where "damage" represents the different damage treatments and "ln (stem weight)" is a continuous variable; their interaction tests whether the relationship between stem and seed biomass (i.e., relative allocation) is affected by the damage treatment.

Data were analyzed using R (R Development Core Team 2008).

\section{Results}

Survivorship was high during the summer: only two plants died after replanting, one in July in the $75 \%$ defoliation treatment, and another in August in the $25 \%$ defoliation treatment. A third was accidentally damaged, leaving 117 plants in the clipping experiment and 60 in the meristem removal experiment.

\section{Direct effects of damage}

Stem biomass decreased with increasing defoliation intensity (Fig. 1: $F_{1,115}=6.52, p=0.012$ ); however the amount of variation explained $\left(r^{2}=0.045\right)$ was slight. In contrast, total seed mass showed no response to defoliation (Fig. 2: $F_{1,115}=0.236, p=0.628$ ). Tests of stem mass (Welch's $t=-0.775$, df $=49.968, \mathrm{p}=0.442$ ) and seed mass (Welch's $\mathrm{t}=0.261, \mathrm{df}=53.338, \mathrm{p}=0.795)$ detected no significant differences between plants with damaged apical meristems and undamaged controls (data shown in Fig. 4).

\section{Size-dependent effects}

The relationship between seed and stem biomass varied across defoliation treatments (Fig. 3). As might be expected, larger plants produced more seeds $\left(\mathrm{F}_{1,109}=98.3, \mathrm{p}<0.001\right)$. Damage treatment also affected size-adjusted seed production $\left(\mathrm{F}_{3,109}=4.47, \mathrm{p}<0.005\right)$ : $5 \%$ leaf removal produced results nearly identical to the undamaged control, but surprisingly, heavier damage tended to increase seed production. There was a strong interaction between defoliation treatment and the slope of the regression of seed mass vs. stem mass $\left(F_{3,109}=3.83, p=0.012\right.$; Fig. 3): relative to the other treatments, 
plants produced fewer seeds per unit stem mass when $75 \%$ defoliated. As a result, small heavily damaged plants produced more seeds than lightly damaged plants of the same size, while reproduction was similar for larger plants regardless of the damage treatment.

Removing the apical meristem had no effect on allocation to reproduction (Fig. 4). Again, stem biomass was an excellent predictor of fecundity $\left(\mathrm{F}_{1,54}=26.53, \mathrm{p}<0.001\right)$, but neither the clipping treatment $\left(\mathrm{F}_{1,54}=0.85, \mathrm{p}=0.36\right)$ nor the size $\times$ treatment interaction $\left(\mathrm{F}_{1,54}=2.76, \mathrm{p}=0.10\right)$ produced a significant result. The full linear model (including treatment, plant size and their interaction) was no better at predicting the total mass of seeds produced than a reduced model including plant size alone (loss of fit: $\mathrm{F}_{2,54}=1.80, \mathrm{p}=0.17$ ).

\section{Discussion}

The major findings of this experiment are i) a very high level of tolerance to both leaf and apical meristem damage in A. artemisiifolia, and ii) evidence that plastic allocation of biomass buffers reproduction against any negative effects of leaf damage. The former conclusion is supported by the slight effect of damage on stem mass and the absence of any discernable effect on absolute seed production. The latter result is supported by increased relative allocation to reproduction in heavily damaged plants. Together, these results suggest that natural enemies are unlikely to limit ragweed populations in either native or invaded areas, and indicate an obstacle to proposed biocontrol efforts.

Simulated damage is not always equivalent to damage by invertebrates (Baldwin 1990), suggesting some caution is required in interpreting our results. However, the levels of leaf damage we applied included treatments far more severe than most plants are likely to naturally experience. For instance, in another experiment at the same site, MacKay and Kotanen (2008) found that $40 \%$ to $58 \%$ of leaves of Ambrosia were damaged by herbivores; however, only a small fraction of area was removed from each leaf. As a result, the average reduction in total leaf area was less than $4 \%$ (MacKay and Kotanen 2008). As well, the damage we applied was in addition to any such natural damage. 
Damage to ragweed is variable among years (MacDonald and Kotanen in revision) and sites (MacKay and Kotanen 2008); nonetheless, it is difficult to believe that our experiment underestimated the effects of natural damage.

Weak effects of damage on plant performance

For damage to limit plant populations, it must have negative consequences for plant performance (Maron and Vilà 2001; Colautti et al. 2004). We were unable to find any relationship between our damage treatments and seed production, though there was a slight effect of defoliation on stem biomass. These results agree with other studies at the same site in which we observed (MacKay and Kotanen 2008) and manipulated (MacDonald and Kotanen in revision) natural damage; in both of these cases, we found no evidence for a negative effect of herbivory. As well, Irwin and Aarssen (1996) reported that ragweed in open habitats was very tolerant of experimental apical meristem removal. In contrast, Throop (2005) reported that leaf damage by the beetle Ophraella communa significantly reduced seed production and some measures of vegetative growth in both field and greenhouse experiments. In these experiments, added beetles were caged on focal plants, but no information was provided regarding the resulting levels of damage. Our experiment would suggest damage levels must have been very high to produce the reported results.

Since ragweed is an annual, the production of seeds is the key step in its life cycle, whereas stem biomass is unlikely to have a direct effect on its population dynamics. Nonetheless, stem biomass may have important indirect effects on the impacts of Ambrosia. Ragweed is problematic in part because it produces copious amounts of wind-dispersed pollen (Bassett and Crompton 1975; Kiss 2007) in terminal inflorescences. This pollen is highly allergenic and a major cause of hayfever. If smaller plants produce less pollen, reductions in stem biomass might reduce the negative health effects of Ambrosia. However, any reduction in pollen density is unlikely to result in fewer seeds: as in many windpollinated annual plants, seed production apparently is not pollen-limited (Friedman and Barrett 2008).

Changes in the relationship between seed production and stem biomass also suggest that the 
tolerance of seed production to damage may benefit from plastic resource allocation. For lightly damaged ragweed plants, allocation to reproduction was nearly proportional to allocation to stem biomass: the slope of the log-log regression is close to one. However, for the most heavily damaged plants, the slope of this relationship declined; as a result, small plants actually produced more seeds than expected, while large plants showed no response to damage. These results suggest plants responded to severe defoliation by diverting resources from further growth to reproduction, especially in the most poorly-performing individuals. In contrast, Throop (2005) reported that leaf damage by $O$. communa resulted in reduced mean reproductive allocation, calculated as (seed mass)/(seed + shoot mass). Again, reasons for the apparent contrast with our results are unclear, but may reflect differences in experimental and analysis strategies; in particular, Throop (2005) did not consider reproductive allometry.

\section{Tolerance and invasions}

Although escape from enemies has attracted more attention, tolerance to those herbivores that an invader encounters in new regions may play an important role in invasions (Bossdorf et al. 2004). Few if any invaders escape all herbivory; instead, most soon are adopted by a new set of herbivores (Hawkes 2007) including both native species and herbivores which themselves have been introduced. Plants with high intrinsic levels of tolerance may be less sensitive to such herbivores than other members of the invaded community, providing them with a competitive advantage. For instance, research in Florida indicates that the invasive Lonicera japonica Thunb. may have an advantage over the native Lonicera sempervirens L. because, as well as experiencing less herbivore damage, $L$. japonica is more tolerant to herbivory than its native congener (Schierenbeck et al. 1994). Similarly, Ashton and Lerdau (2008) found that in a greenhouse experiment, invasive vines were more tolerant of simulated herbivory than native and non-invasive species. Tolerance may have important indirect effects as well: if tolerant exotics can support large herbivore populations, this herbivore load may spill over onto the native flora, resulting in apparent competition in favour of the exotic (White et al. 2006). 
Finally, highly tolerant invaders may be difficult targets for biological control. Our results suggest that biocontrol of ragweed by invertebrate folivores would require damage far in excess of native-range levels; although this might be possible in a region where the folivores' own enemies were absent, this represents an additional barrier to biocontrol efforts, and may help to explain why European attempts have so far been unsuccessful (Reznik et al. 1994; Igrc et al. 1995; Kiss 2007).

While many studies of the Enemy Release Hypothesis focus on the damage experienced by exotic plants (Colautti et al. 2004; Torchin and Mitchell 2004; Liu and Stiling 2006), the relationship between damage and fitness often is overlooked (Maron and Vilà 2001). If a plant is highly damagetolerant, loss of enemies may occur during invasion without an increase in invasiveness. Our results suggest this may be the case for ragweed: low levels of native-range damage coupled with weak effects of damage on fitness suggest that though escape from enemies may have occurred in exotic populations of this species, the consequences of this escape may have been small. Instead, the presence of suitably disturbed sites may have played a far greater role in invasions by this species (Chauvel et al. 2006; Kiss 2007; Fumanal et al. 2008). Although enemy release may play a crucial role in invasion by some species (e.g., DeWalt et al. 2004), loss of enemies need not translate to a critical advantage.

\section{Acknowledgments}

M. Saunders, K.A. Judge, L.J. Robson and two anonymous reviewers for useful comments. A.

Simonsen, R. Dinnage, Z. Burivalova, R. MacKenzie, A.M. Petersen, V. Pham and especially K. Kostyukova for help with field work. J. Stinchcombe and S.C.H. Barrett for advice, A. Weis and KSR for logistical support. This work would have been impossible without the donation of KSR to the U of Toronto by the Koffler family. This work was supported by an NSERC PGS to A.A.M.M. and an NSERC Discovery Grant to P.M.K. 


\section{References}

Allard, H.A. 1943. The North American ragweeds and their occurrence in other parts of the world.

Science, 98: 292-294.

Ashton, I.W., and Lerdau, M.T. 2008. Tolerance to herbivory, and not resistance, may explain differential success of invasive, naturalized, and native North American temperate vines. Divers. Distrib. 14: 169-178.

Baldwin, I. 1990. Herbivory simulation in ecological research. Trends Ecol. Evol. 5: 91-93.

Baskin, J.M., and Baskin, C.C. 1980. Ecophysiology of secondary dormancy in seeds of Ambrosia artemisiifolia. Ecology, 61: 475-480.

Bassett, I.J., and Crompton, C.W. 1975. Biology of Canadian weeds 11. Ambrosia artemisiifolia L. and A. psilostachya Dc. Can. J. Plant Sci. 55: 463-476.

Bassett, I.J., and Terasmae, J. 1962. Ragweed, Ambrosia spp., in Canada and their history in postglacial time. Can. J. Bot. 40: 141-150.

Bazzaz, F.A. 1968. Succession on abandoned fields in the Shawnee Hills, southern Illinois. Ecology, 49: 924-936.

Bazzaz, F.A. 1974. Ecophysiology Of Ambrosia artemisiifolia - successional dominant. Ecology, 55: 112-119.

Bazzaz, F.A., and Mezga, D.M. 1973. Primary productivity and microenvironment in an Ambrosia dominated old-field. Am. Midl. Nat. 90: 70-78.

Bossdorf, O., Schröder, S., Prati, D., and Auge, H. 2004. Palatability and tolerance to simulated herbivory in native and introduced populations of Alliaria petiolata (Brassicaceae). Am. J. Bot. 91: 856-862.

Chauvel, B., Dessaint, F. Cardinal-Legrand, C., and Bretagnolle, F. 2006. The historical spread of Ambrosia artemisiifolia L. in France from herbarium records. J. Biogeog. 33: 665-673. 
Colautti, R.I., Ricciardi, A., Grigorovich, I.A., and MacIsaac, H.J. 2004. Is invasion success explained by the enemy release hypothesis? Ecol. Lett. 7: 721-733.

DeWalt, SJ, Denslow, J.S., and Ickes, K. 2004. Natural-enemy release facilitates habitat expansion of the invasive tropical shrub Clidemia hirta. Ecology, 85: 471-483.

Dodd, M.E., and Silvertown, J. 2000 Size-specific fecundity and the influence of lifetime size variation upon effective population size in Abies balsamea. Heredity, 85: 604-609.

Elton, C.S. 1958. The ecology of invasions by animals and plants. Methuen, London.

Foster, M.M., Vitousek, P.M., and Randolph, P.A. 1980. The effects of ragweed (Ambrosia artemisiifolia L.) on nutrient cycling in a 1st-year old-field. Am. Midl. Nat. 103: 106-113.

Friedman J., and Barrett, S.C.H. 2008. High outcrossing in the annual colonizing species Ambrosia artemisiifolia (Asteraceae). Ann. Bot. 101: 1303-1309.

Fumanal, B., Girod, C., Fried, G., Bretagnolle, F., and Chauvel, B. 2008. Can the large ecological amplitude of Ambrosia artemisiifolia explain its invasive success in France? Weed Res. 48: 349-359. Funk, D.J., Futuyma, D., Ortí, G., and Meyer, A. 1995. A history of host associations and evolutionary diversification for Ophraella (Coleoptera: Chrysomelidae): new evidence from mitochondrial DNA. Evolution, 49: 1008-1017.

Futuyma, D.J., and McCafferty, S.S. 1990. Phylogeny and the evolution of host plant associations in the leaf beetle genus Ophraella (Coleoptera: Chrysomelidae). Evolution, 44: 1885-1913.

Genton, B.J., Kotanen, P.M., Cheptou, P.O., Adolphe, C., and Shykoff, J.A. 2005. Enemy release but no evolutionary loss of defence in a plant invasion: an inter-continental reciprocal transplant experiment. Oecologia, 146: 404-414.

Hawkes, C.V. 2007. Are invaders moving targets? The generality and persistence of advantages in size, reproduction, and enemy release in invasive plant species with time since introduction. Am. Nat. 170: 832-843.

Hierro, J.L., Maron, J. L., and Callaway, R.M. 2005. A biogeographical approach to plant invasions: the 
importance of studying exotics in their introduced and native range. J. Ecol. 93: 5-15.

Hurlbert, S.H. 1984. Pseudoreplication and the design of ecological field experiments. Ecol. Monogr., 54: 187-211.

Igrc, J., Deloach, C.J. and Zlof, V. 1995. Release and establishment of Zygogramma suturalis F (Coleoptera, Chrysomelidae) in Croatia for control of common ragweed (Ambrosia artemisiifolia L). Biol. Contrl. 5: 203-208.

Irwin, D.L., and Aarssen, L.W. 1996. Testing for cost of apical dominance in vegetation: a field study of three species. Ann. Bot. Fennici 33: 123-128.

Keane, R.M., and Crawley, M.J. 2002. Exotic plant invasions and the enemy release hypothesis. Trends Ecol. Evol. 17: 164-170.

Kiss, L. 2007. Why is biological control of common ragweed, the most allergenic weed in Eastern Europe, still only a hope? In Biological control: a global perspective. Edited by C. Vincent, M.S. Goettel and G. Lazarovits. CABI, Wallingford, pp. 80-91.

Kosola, K.R., and Gross, K.L. 1999. Resource competition and suppression of plants colonizing early successional old fields. Oecologia, 118: 69-75.

Liu, H., and Stiling, P. 2006. Testing the enemy release hypothesis: a review and meta-analysis. Biol. Inv. 8: 1535-1545.

MacDonald, A.A.M., and Kotanen, P.M. In revision. The effects of disturbance and enemy exclusion on performance of an invasive species, common ragweed, in its native range. Oecologia.

MacKay, J., and Kotanen, P.M. 2008 Local escape of an invasive plant, common ragweed (Ambrosia artemisiifolia L.), from above-ground and below-ground enemies in its native area. J. Ecol. 96: 11521161.

Maron, J.L., and Vilà, M. 2001. When do herbivores affect plant invasion? Evidence for the natural enemies and biotic resistance hypotheses. Oikos, 95: 361-373.

Maryushkina, V.Y. 1991. Peculiarities of common ragweed (Ambrosia artemisiifolia L.) strategy. Agr. 
Ecosyst. Environ. 36: 207-216.

McAndrews, J.H. 1988. Human disturbance of North American forests and grasslands: the fossil pollen record. In Vegetation history. Edited by B. Huntley and T. Webb III. Kluwer Academic Publishers. Dordrecht, pp 673-697.

Mitchell, C.E., and Power, A.G. 2003. Release of invasive plants from fungal and viral pathogens. Nature, 421: 625-627.

Mitchell, C.E., Agrawal, A.A., Bever, J.D., Gilbert, G.S., Hufbauer, R.A., Klironomos, J.N., Maron, J.L., Morris, W.F., Parker, I.M., Power, A.G., Seabloom, E.W., Torchin, M.E., and Vázquez, D.P. 2006. Biotic interactions and plant invasions. Ecol. Lett. 9: 726-740.

Paquin, V., and Aarssen, L.W. 2004. Allometric gender allocation in Ambrosia artemisiifolia (Asteraceae) has adaptive plasticity. Am. J. Bot. 91: 430-438.

R Development Core Team. 2008. R: A language and environment for statistical computing. R Foundation for Statistical Computing, Vienna, Austria.

Reznik, S.Y., Belokobyl'skiy, S.A., and Lobanov, A.L. 1994. Weed and herbivorous insect population densities at the broad spatial scale: Ambrosia artemisiifolia L. and Zygogramma suturalis F. (Col., Chrysomelidae). J. Appl. Ent. 118: 1-9.

Rosenthal, J.P., and Kotanen, P.M. 1994. Terrestrial plant tolerance to herbivory. Trends Ecol. Evol. 9: 117-157.

Schierenbeck, K.A., Mack, R.N., and Sharitz, R.R. (1994) Effects of herbivory on growth and biomass allocation in native and introduced species of Lonicera. Ecology, 75: 1661-1672.

Sokal, R.R. and Rohlf, F.J. 1995. Biometry: the principles and practices of statistics in biological research (3rd edn.). W.H. Freeman, New York.

Stevens, M.H.H., and Carson, W.P. 1999. Plant density determines species richness along an experimental fertility gradient. Ecology, 80: 455-465.

Stowe, K.A., Marquis, R.J., Hochwender, C.G., and Simms, E.L. 2000. The evolutionary ecology of 
tolerance to consumer damage. Annu. Rev. Ecol. Syst. 31: 565-595.

Strauss, S.Y., and Agrawal, A.A. 1999. The ecology and evolution of plant tolerance to herbivory. Trends Ecol. Evol. 14: 179-185.

Teshler, M.P., DiTommaso, A., Gagnon, J.A., and Watson, A.K. 2002. Ambrosia artemisiifolia L. common ragweed (Asteraceae). In: Biological control programs in Canada 1981-2000. Edited by P.G. Mason and J.T. Huber. CABI, Wallingford, pp. 290-294.

Throop, H.L. 2005. Nitrogen deposition and herbivory affect biomass production and allocation in an annual plant. Oikos, 111: 91-100.

Tiffin, P. 2000. Are tolerance, avoidance, and antibiosis evolutionarily and ecologically equivalent responses of plants to herbivores? Am. Nat. 155:128-138.

Tiffin, P., and Inouye, B.D. 2000. Measuring tolerance to herbivory: accuracy and precision of estimates made using natural versus imposed damage. Evolution, 54: 1024-1029

Torchin, M.E., and Mitchell, C.E. 2004. Parasites, pathogens, and invasions by plants and animals. Front. Ecol. Environ. 2: 183-90.

White, E.M., Wilson, J.C., and Clarke, A.R. 2006. Biotic indirect effects: a neglected concept in invasion biology. Divers. Distrib. 12: 443-455. 


\section{Figure Captions}

Figure 1. Response of stem biomass to the removal of leaves. Treatments are $75 \%$ removal, $25 \%$ removal, $5 \%$ removal, and undamaged controls. Points represent individual plants. The line indicates a significant linear regression $(\mathrm{p}=0.012)$.

Figure 2. Response of seed production to the removal of leaves. Treatments are $75 \%$ removal, 25\% removal, 5\% removal, and undamaged controls. Points represent individual plants. Linear regression analysis did not detect a significant relationship ( $p>0.05)$.

Figure 3. Relationship between total seed biomass and stem biomass for different leaf removal treatments. Treatments are 75\% removal, 25\% removal, 5\% removal, and undamaged controls. Points represent individual plants. Lines indicate estimated regressions for each treatment; slope depends on the damage treatment $\left(\mathrm{F}_{3,109}=3.83, \mathrm{p}=0.012\right)$.

Figure 4. Relationship between total seed biomass and stem biomass for apical damage treatments. Treatments are apical removal, and undamaged controls. Points represent individual plants; controls are the same as in Figure 3. Lines indicate estimated regressions for each treatment; slopes do not differ statistically $\left(\mathrm{F}_{1,54}=2.76, \mathrm{p}=0.10\right)$. 


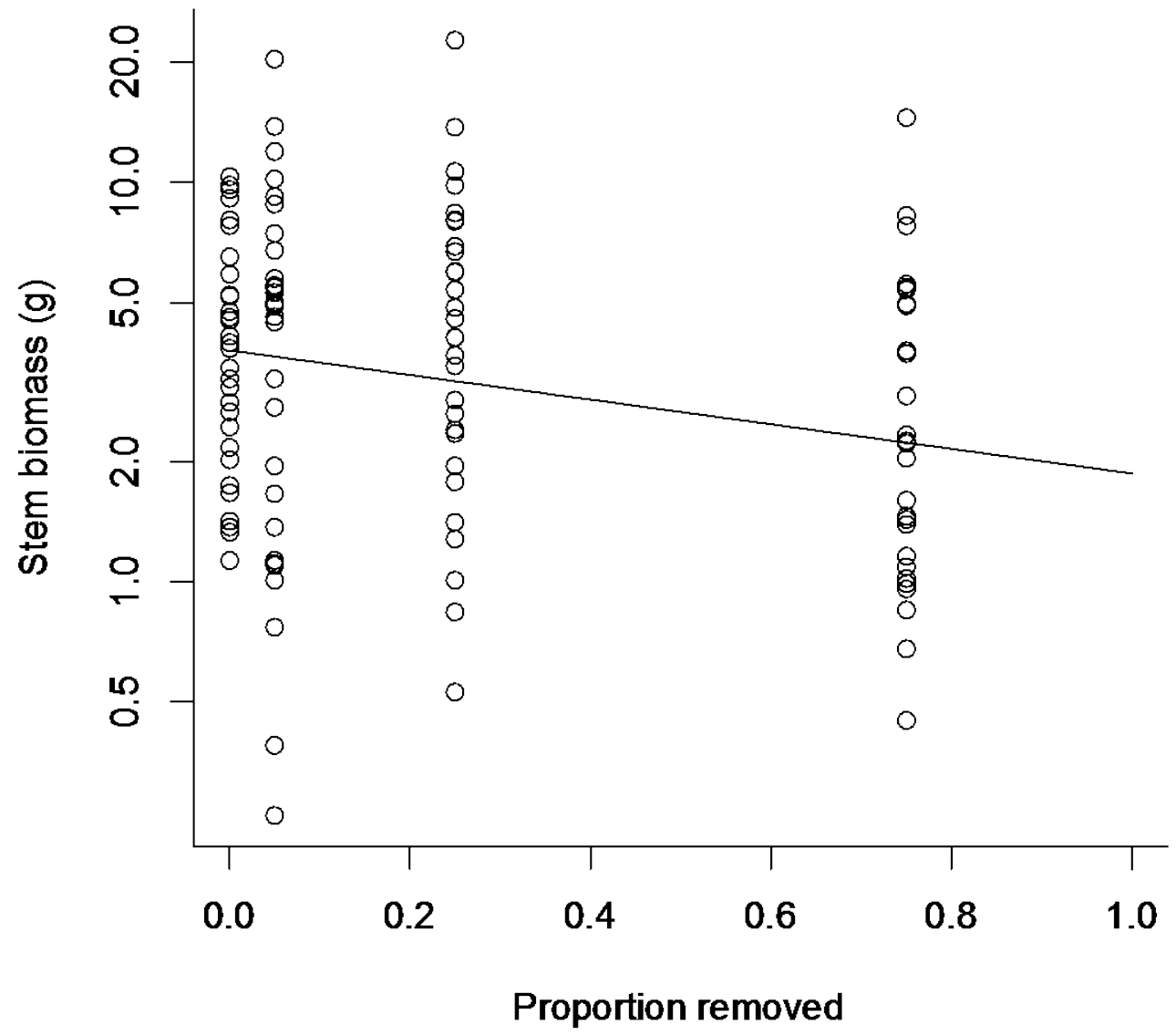




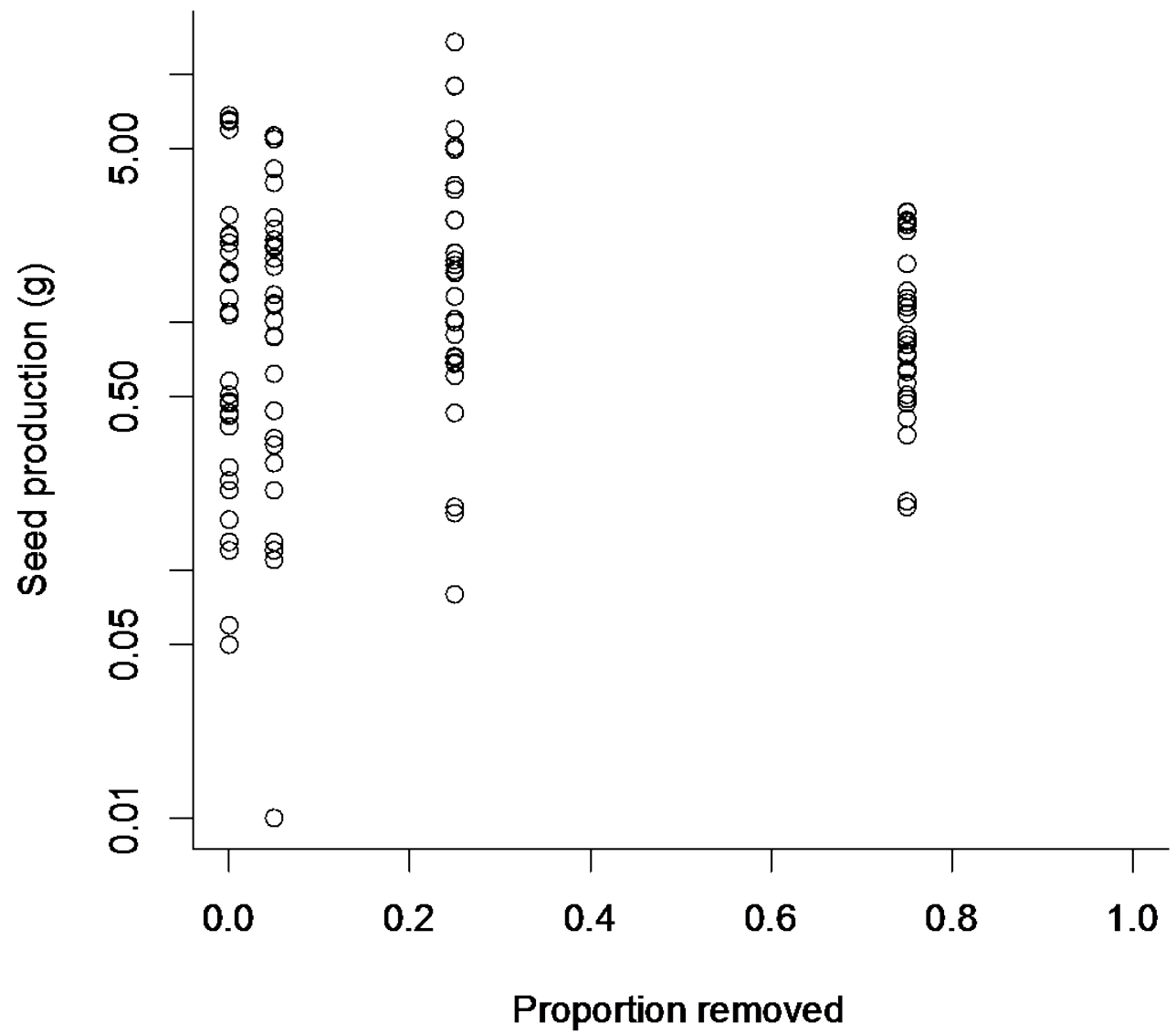




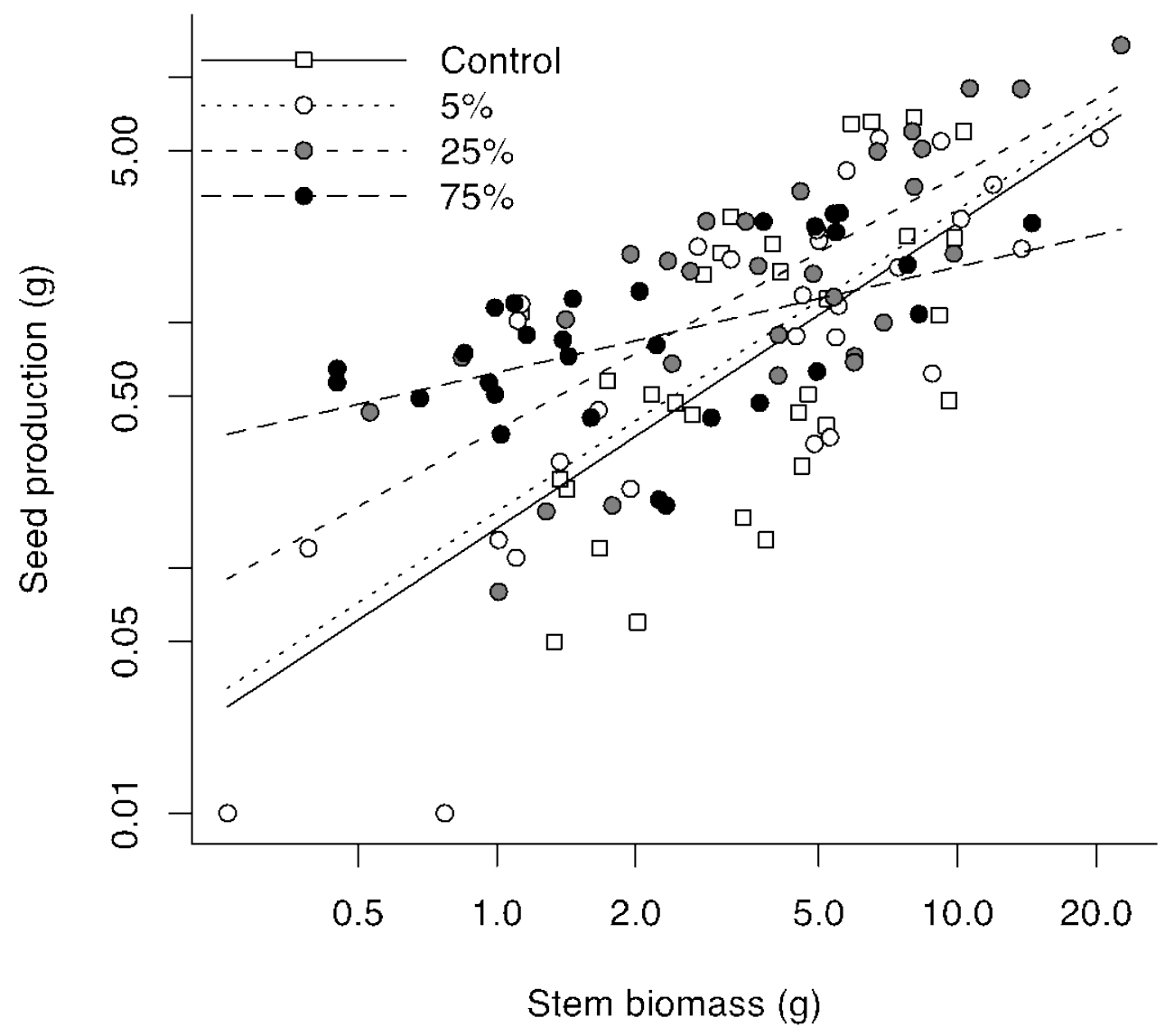




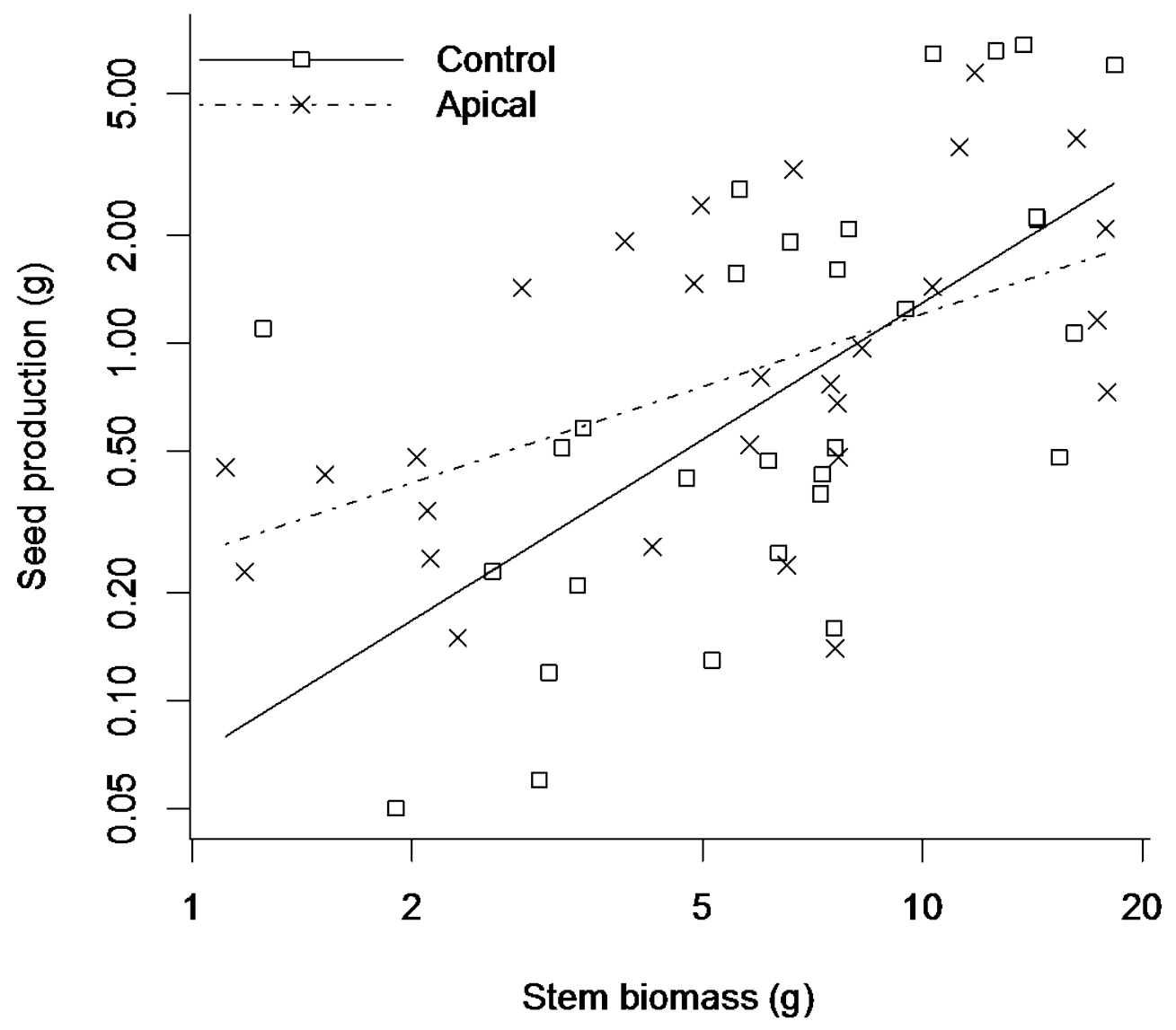

